\title{
On the Development of the Cystocarp in Rhodomelaceae.
}

\author{
BY \\ REGINALD W. PHILLIPS, M.A., B.Sc., \\ Professor of Botany in the University College of North Wales, Bangor.
}

With Plate $\mathbf{X}$.

T

HE Rhodomelaceae constitute one of the most natural of all the families of the Red Seaweeds. They are characterized among other things by the globular, oval, or urceolate fructification, opening by a terminal pore, and usually standing out from the thallus, a condition which is familiar to us in the 'ceramidium' of the genus Polysiphonia. Agardh, surveying the group once more in his recent Analecta Algologica (1), says :- 'Those characters which long ago (2) seemed to me to belong to this group: the polysiphonous thallus, the form and structure of the cystocarp, the nucleus consisting of sporiferous free threads, giving rise to pyriform spores in their terminal clavate joints, and finally sphaerospores evolved in the pericentral cells, and arranged in a fixed order ; these seem to me to-day to mark out a family distinct from all others.' And although Schmitz has shown (3) that the mode of development of the cystocarp should be an important consideration in the taxonomy of the Florideae, it

[Annals of Botany, Vol. IX. No. XXXIV. June, 1895.]. 
is probable that the Rhodomelaceae will be less disturbed by the introduction of this new criterion than almost any other family. So far, the most important rearrangements proposed by Schmitz and Falkenberg (4) consist in the transference of four of Agardh's list of thirty-nine genera to the Delesseriaceae; and the removal from Agardh's Chondrieae into the Rhodomelaceae, of Laurencia and certain later allied genera. The limits of the family are thus not seriously changed, and it remains one of the largest and best-defined of all the Floridean groups.

Our knowledge of the minute structure of the cystocarp in the Rhodomelaceae, as in the rest of the Florideae, received a new impulse upon the publication, in 1883 , of Schmitz's researches upon the process of fertilization. For the first time the study of the development of the cystocarp in detail, brought up our knowledge of the morphology of the female reproductive organ of the Florideae, to the level which it had long before reached in other groups of plants. The discoveries of Schmitz are a worthy continuation of those of Bornet and Thuret, and Janczewski. As a result of his investigations, Schmitz conceived the luminous idea that the thallus of all Florideae (in the narrower sense in which he uses the term, i.e. excluding the Bangiaceae) consists of branched filaments; that these filaments grow by means of an apical cell ; and that no segment is subsequently divided by a transverse septum, or by a longitudinal septum which passes through the organic axis. Though this theory has since been found by Johnson (5) and by Schmitz himself (6) not to hold good for the Nitophylleae, a single tribe of the Delesseriaceae, it is probably of very general application in the Florideae, and certainly throughout all the Rhodomelaceae. It was when this theory was applied to the study of the developing cystocarp of this family, and the cell-connexions traced by means of the characteristic Floridean pit, that a clue was first obtained to its inner structure.

My own attention was directed to the study of this organ by the account given by the author of aberrations presented 
by Chondria tenuissima, Ag., in the process of the maturation of the cystocarp. This plant differed in some important details from the other members of the family which he had examined, and Schmitz entertained a belief that similar departures would be found elsewhere. I therefore examined such suitable material as I could collect, and have now investigated the earlier stages of the cystocarp in several species of the genera Rhodomela and Polysiphonia, four of them with some detail. As might have been expected perhaps from the narrow limits covered by the species, no considerable variation of structure has been observed; it is rather the uniformity which is the more remarkable. Some of the results which have been obtained, it may, however, be of interest to publish, more especially as the monograph on the Florideae upon which Schmitz, in collaboration with Falkenberg for the Rhodomelaceae, has long been engaged, is not likely to appear for some time yet.

The account of the formation of the cystocarp in Rhodomelaceae in the paper already referred to, is necessarily somewhat meagre, as the communication was avowedly of a preliminary nature, and covered the whole of the Florideae. A supplementary description ( 7 ) has since appeared, adding the result of later investigation. The earlier account is accompanied by only one figure illustrating the group under consideration. Excellent figures of Chondria tenuissima have been given by Janczewski (8) and again by Bornet and Thuret in the Etudes phycologiques (9); but in both works the description fails at the point which Schmitz has since made so interesting. The figures of Polysiphonia variegata, Zanard., in Schenck's Handbuch (10) would now have to be revised by Falkenberg in the light of the researches of his colleague. The description given by Van Tieghem in the latest edition of the Traité de Botanique (11) of the structure of the cystocarp in Polysiphonia errs in the same particulars as do Falkenberg's description and figures, which is the more remarkable as this author has embodied in the same work the classification which Schmitz founds upon his researches. 
No other writers, as far as I am aware, describe the structure in detail. As Polysiphonia is the genus oftenest selected for examination as a convenient type of the Florideae, it is an additional reason for submitting a more detailed description of the procarps than has yet appeared.

\section{Rhodomela subfusca (Woodw.), Ag.}

Figs. 1, 2, 3, 4.

This Alga is recorded in Holmes and Batter's list (12) as occurring in all the fourteen districts into which they mark out the British coast. The specimens which I have examined were collected on the south coast of Anglesey, where the plant presents a peculiarity of habit to which Harvey makes no reference, but which reminds one of the description given by Kjellman (13) for his new species Rhodomela virgata. It is a perennial plant, but is severely cut down in the autumn to a few of its main axes, chiefly I believe owing to the depredations of molluses which seem to find its finer ramifications an agreeable food. Early in the spring plants thus reduced bud out irregularly a large number of new branches, reminding one of the behaviour of a polled or, rather, a severelypruned willow or lime. These branches invariably bear in their earlier stages reproductive organs, and I have collected specimens with cystocarps, antheridia, and tetraspores respectively. The branches bearing cystocarps are minute corymbose tufts, densely covered with procarps in all stages of development. While yet the branch is hardly a millimetre in length and breadth, the lower cystocarps are apparently mature, containing a few well-developed carpospores. Most of these procarps, as may be thought, do not become fertilized, and the procarpial branches then proliferate into vegetative shoots of the ordinary pattern. Larger branches bearing cystocarps, as figured by Harvey, I have not yet collected. These small branches afford excellent material for the study of the development of the cystocarp, and it is from an examination of them that the following description was obtained. 
The branch destined to bear the cystocarp consists of from eight to twelve joints. The first becomes the stalk of the cystocarp. The second is the reproductive joint proper, giving rise to the greater part of the pericarp, and the whole of its contents. The third is included in the cystocarp with the products of the second joint, but has no further history. All the remaining cells of the filament wither off when fertilization has taken place, leaving eventually no mark of their presence.

The first joint forming the stalk cuts off from the central cell five pericentral cells. Other cells are derived later from these, giving rise to a cortex, similar to that which characterizes the vegetative parts. Some cells of this number contribute to form the inferior part of the pericarp.

The second joint is that from which springs the carpogonial branch. Five pericentral cells are here also cut off from a central cell. The last formed is ventral, i. e. in the median position above. The two pericentral cells on the dorsal side divide but slightly. The two cells right and left of these divide rapidly (Fig. 10), forming two plates of cells protruding ventrally so as to enclose as a rudimentary pericarp the fifth pericentral cell. The two lateral convex plates thus arising and leaving a median gap above and below have been compared to the paired valves of a bi-valve shell-fish. Later on this two-sidedness disappears, the wall becoming globular by the filling up of the median gaps. The fifth pericentral cell, enclosed as thus described, gives rise to the carpogonial branch. It forms, moreover, two other branches, a one-celled branch in the median position below, and another two-celled branch directed laterally upward. The carpogonial filament is lateral also, facing the second of the two branches referred to above. It consists of four cells and is directed upward. The end cell is the carpogonium and is prolonged into a trichogyne which passes out medianly above in the gap of the pericarp, which is as yet bi-valve (Fig. 1). The carpogonial branch is curved into a crescent in a plane which is not quite median, but the long trichogyne usually lies parallel to 
the terminal filament (Figs. 2, 3, 5, 7). The curvature of the carpogonial branch is such that, as has been described by Schmitz, the carpogonium itself lies medianly above and close to the pericentral cell, from which the carpogonial branch arose. This pericentral cell was first regarded by Schmitz as the auxiliary cell, but he now regards a later derivative of it, which had previously escaped his notice, as the true auxiliary cell (7). There is, however, some reason for adhering to his first statement, and I will return to this point again, describing the pericentral cell as the auxiliary for the present. The carpogonial branch does not occupy a definite position in the young cystocarp right or left of the two-celled lateral branch, from which it may be inferred, I think, that this lateral branch is the morphological equivalent of the carpogonial branch.

The derivatives of the pericentral (auxiliary) cell at this stage consist therefore of the following:-

(a) A four-celled carpogonial branch, ending in the carpogonium with its trichogyne;

(b) A two-celled sterile lateral branch facing it;

(c) A one-celled sterile inferior branch.

In the majority of the numerous procarps which are crowded on the tufted branches of this plant, no fertilization takes place. The procarps do not, however, thereupon atrophy and disappear, but, as before stated, are gradually metamorphosed into vegetative shoots. The plant thus offers a convenient opportunity of sharply distinguishing between the condition of the procarp before fertilization and the developments which are consequent upon fertilization. With regard to the proliferation itself, it is not clear how it is effected, what cell for example of the former procarp becomes the leading-cell of the branch. Two points are clear, however. First, that no cell of the axial row becomes the apical cell, so that the proliferated branch is a sympodium ; secondly, that all the cells of the former procarp become active, living, cells of the branch, excepting only the four cells of the carpogonial branch. The carpogonium itself on the failure of fertilization becomes ill- 
defined and cannot be traced; but the three other cells of the branch remain imbedded among the cortical cells of the new branch as a row of diminutive cells,--dead and deeply stained with their own colouring matter. I have seen one instance of a similar proliferated appendage with an atrophied carpogonial branch in Chondria tenuissima.

When fertilization, however, occurs, immediate changes ensue in the procarpial structures. Cases where the spermatium is still adhering to the trichogyne may be observed commonly; but I was unable by the closest observation to discover the conjugation-process or ooblastema, by which the carpogonium and the auxiliary cell are put into communication with each other. One cannot, however, doubt but that, as Schmitz affirms, such a fusion of the contents of the carpogonium with those of an auxiliary cell, whether the pericentral cell or a derivative, does take place. The comparative study of other Floridean groups, and the subsequent history of the procarpial cells, combine to render the fact almost certain. In the absence of direct ocular proof of the phenomenon in this group Schmitz is led to wonder whether the process may not be one of fertilization rather than conjugation, i. e. one in which there is a transference of nuclear matter through fine pores, rather than an emptying of the whole or greater part of the contents through a relatively large pit. It is certain that the carpogonium remains distinguishable even after the formation of spores, which seems to tell in favour of a process of fertilization properly so called. It has occurred to me that the actual fusion may take place in the night, as is well known to be the case with some of the Green Algae. The fact remains that, up to the present, no trace of the ooblastema-thread from the fertilized carpogonium has been observed. In Rhodomela subfusca, the consequences of fertilization are three-fold, First, the auxiliary cell itself shuts off a large cell from its upper part, just the region, it may be noted, with which conjugation must have been effected. At first it might seem that the auxiliary cell had divided into two almost equal parts. Close examination, however, shows that all four pit-connexions, 
which belong to the auxiliary cell, that with the central cell, and those with all three of its branches, remain with the inferior cell. The auxiliary cell has in fact given rise to a new branch consisting of one cell, and it is this derived cell which Schmitz in his later account considers the true auxiliary cell. From it the sporogenous filaments-meta-ooblastemata as Schmitz has called them-arise. These meta-ooblastemata branch freely in a sub-dichotomous fashion, and form the close-set mass of filaments known formerly as the 'nucleus,' the terminal cells of which ultimately discharge the denselycoloured pyriform carpospores.

The effect of the formation of the 'nucleus' upon the cells of the carpogonial branch is to detach them from their pitconnexion with the auxiliary cell, and to push them outward towards the pore, where, thus shunted, they may still be detected at a late stage as a row of shrunken cells (Figs. 4, 6, 14).

The second effect of fertilization is that upon the two sterile branches. The inferior one-celled branch adds a new cell, while each of the two cells of the two-celled branch buds off a new cell; so that the sterile products of the auxiliary cell now number six cells. Beyond this the development does not go; but as the cystocarp becomes filled with carpospores it becomes difficult to trace the changes in the sterile tissue. The six sterile cells may still be seen at a late stage of sporeformation (Fig. 4).

A third effect of fertilization is the branching of the central cell itself laterally, into two cells which branch again and again, forming at length about twelve filaments which line the whole cavity of the cystocarp extending as far as the pore (Fig. 9). The wall of the cystocarp is properly only one cell thick, but the existence of this layer gives it the appearance of being two cells thick. The cells of the lining do not, however, form a pseudo-parenchyma as do those of the pericarp, but retain their filamentous character to the end, separated laterally by a wide interval, circumstances which render them easy of identification. These cells are no doubt the paranemata of 
Agardh (14) (Figs. 8, 9), which he states he observed in Polysiphonia violacea and other species of Polysiphonia, and also in Vidalia. They may be observed to become more and more attenuated and inconspicuous with the maturation of the carpospores, and it has occurred to me that a possible function is the supply of the plentiful mucilage which is found in the cystocarp when mature and which carries out the ripe spores with it as it escapes through the pore. That they play the rôle of a tapetum, and contribute to the nutrition of the spores, is hardly probable. Whatever the function of these paranemata, it is clear that they do not arise from the auxiliary cell, but from the subjacent central cell itself. They cannot therefore be regarded as sterile elements of the 'nucleus'; they have an origin quite distinct.

\section{Polysiphonia nigrescens, Grev.}

Figs. 7, 8, 10, 11 I I 2.

This species is common everywhere on the British coast. It belongs to that subdivision of the genus which Holmes and Batters describe as 'Polysiphoniae ecorticatae.' The apical region is in spring densely clothed with leaves, as the monosiphonous, freely-branched, hairlike appendages have been called, and it is modifications of these that bear antheridia and procarps. While it would be out of place here to discuss the external morphology of the Rhodomelaceae, it may be pointed out that Nägeli and later writers have distinguished between two kinds of appendages in Florideae, leaves and branches; and Kny (15) has further discovered that, in some cases, in Chondria tenuissima for example, the same relationship exists between these appendages as exists in the higher plants. In Rhodomela subfusca these leaf-like appendages do occur, though not on the tufted procarp-bearing branches which I have described, where the procarps proliferate into ordinary branches, and would thus seem to be their morphological 
equivalents. In Polysiphonia nigrescens the antheridia and procarps are modified leaves branching beyond the fertile region in the same manner as the ordinary leaves branch.

The formation of the cystocarp corresponds in every essential particular to that already described for Rhodomela subfusca. The cell-divisions constituting the pericarp may be followed with greater ease in this species than in Rhodomela subfusca. Speaking generally, it may be said that the ecorticated species of Rhodomelaceae have a more simply-formed pericarp than have the corticated species. The origin of the paranemata in a pair of cells derived laterally from the central cell may be clearly traced; though I believe I have seen that, in the median line below, a row of paranematal cells is derived from a pericentral cell of the first joint, forming the stalk of the cystocarp. The subdivision of the auxiliary cell after fertilization into a superior sporogenous and an inferior sterile cell, I have only been able to see rarely. The difficulty arises from the fact that a much larger number of carpospores is formed in this species than in Rhodomela subfusca. This dense 'nucleus' consisting of from ten to twenty times as many spores as occur in Rhodomela, obscures the changes taking place at the core of the fructification. The greater drain upon the resources of the sporogenous cell due to the formation of a large number of carpospores, probably accounts for a phenomenon which distinguishes this species from the other. I refer to the apparent retrogressive absorption by the sporogenous cell of the auxiliary cell and later, of all its sterile derivatives, leaving in its place a large multipolar, multinucleate sporogenous mass, which may be occasionally squeezed out from nearly ripe cystocarps, and two of which I figure (Figs. 11, I2). I have never been able to see such absorption in Rhodomela subfusca, and it is certain that in that species the auxiliary cell and all its sterile derivatives remain at a relatively late period of spore-formation. In Polysiphonia nigrescens, on the other hand, I have failed to trace the sterile elements when once spore-formation has well set in. 
Polysiphonia fastigiata (Roth), Grev.

Fig. 9 .

This species is readily identified as a common epiphyte on Ascophyllum nodosum, Le Jol, and is probably on this account usually selected for description as a type of the Florideae. It comes very near $P$. nigrescens by general consent, but differs from that species in the total absence of leaves. The development of the cystocarp is closely comparable with that of $P$. nigrescens, but is somewhat more difficult to follow on account of the greater compactness of the procarp. When the sporogenous cell has been segmented off, the first sporigerous filament consisting of two cells appears in line with the sporogenous and the auxiliary cells, presenting the appearance of three equivalent sporogenous cells. The whole contents of the procarp may readily be squeezed out by gentle pressure in this species, and as the cells are held together by the pit-connexions, it is possible to make out the relationship, though the disturbance makes it occasionally puzzling. It is the pit-connexion with the central cell which gives way on this treatment. When from a fertilized procarp more than eight cells are thus squeezed out, in addition to the remains of the carpogonial branch, it is due I believe to the inclusion of rudimentary sporigerous filaments.

I have been unable to trace the sterile cells in maturer cystocarps. They probably undergo absorption by the sporogenous cells during the spore-formation.

The paranemata are very clear and may be noticed even after the discharge of the spores.

During the enlargement of the cystocarp, the parietal cells bud to form an imperfect cortex, closely encased in the old cuticle, but the pericarp cannot be said to be two cells thick continuously. 
Polysiphonia violacea (Roth), Grev.

Figs. 5, 6.

$P$. violacea differs from those already described in the possession of four siphons, the smallest number known in the genus. The siphons of $P$. fastigiata reach as many as twenty in parts, and those of $P$.nigrescens a larger number still, but both are free from the so-called cortex of $R$ hodomela subfusca. Rosenvinge(16) in his paper on the morphology of the genus regards $P$. nigrescens, fastigiata, and violacea as types of as many groups within the genus, and to these species he largely devotes his attention. It is therefore interesting to find that in all essential respects the structure of the cystocarp in Polysiphonia violacea is cell for cell comparable with that of the three species already enumerated.

The only point of difference arises when the history of the sporogenous derivative of the auxiliary cell is traced subsequent to spore-formation. Under P. nigrescens it has been stated that the sporogenous cell seems to absorb the cell from which it sprang, and even the sterile derivatives of that cell. In $P$. violacea the process of fusion goes even farther, to the inclusion, that is to say, of the central cell itself. Here again I cannot say whether the cells of the sterile branches, more especially the peripheral cells, are absorbed or atrophy; they cannot, however, be traced in the maturer cystocarps, where a large multinucleate mass confluent with the central cell may be observed. There can be no doubt, however, that the earlier carpospores are derived directly from the sporogenous derivative of the auxiliary cell, and we may fairly infer that when fusion with other cells occurs later, it is daughter-nuclei of this cell, or perhaps daughternuclei of the auxiliary cell, which furnish the nuclei of the carpospores. 


\section{Conclusions.}

It is clear from what has been said that the four species examined present a remarkable uniformity in the structure of the procarp at the moment of fertilization; the fifth and lastformed pericentral cell facing the axis giving rise to three branches :-

(a) A four-celled lateral carpogonial branch;

(b) A two-celled lateral sterile branch;

(c) A one-celled inferior sterile branch.

After fertilization there is also complete correspondence up to the formation of carpospores :-

(a) The carpogonial branch is shunted off and withers.

(b) The two-celled lateral sterile branch branches again and becomes four-celled.

(c) The one-celled inferior branch adds a cell.

(d) The fifth pericentral cell, now the auxiliary cell, shuts off a superior sporogenous cell.

(e) The central cell gives off laterally two cells from which numerous (about twelve) paranematal filaments are derived, converging to the pore, and forming an imperfect lining.

The divergences come in when spore-formation has proceeded to some length :-

(a) In Rhodomela subfusca no absorption of neighbouring cells by the sporogenous cell takes place at a late period in the formation of spores, if at all.

(b) In Polysiphonia nigrescens and $P$. fastigiata such absorption does take place, extending to the auxiliary cell and the sterile branches.

(c) In $P$. violacea the absorption extends to the central cell.

The paranematal layer is probably constant in Rhodomelaceae. I have seen it in Polysiphonia sertularioides, $P$. byssoides, $P$. urceolata, and Chondria temissima, in addition to the species mentioned above.

To revert now to the comparison of these species with 
the somewhat aberrant condition described by Schmitz for Chondria tenuissima. Here also it would seem that two sterile branches are formed in the procarp, but in this case they are 'luxuriantly ramified.' After fertilization, conjugation takes place between the auxiliary cell and the nearest cells of these branches, leaving numerous peripheral filaments unabsorbed, and this takes place before spore-formation begins. Finally, from the multinucleate mass resulting from conjugation a superior portion is segmented off, and from this the spore-bearing filaments arise.

The most important difference is clearly the wholesale conjugation before spore-formation, and the subsequent differentiation of a sporogenous portion from the resulting mass.

The absorption which takes place in Polysiphonia, I am inclined to regard as of little value for taxonomic purposes. It is a physiological process, varying probably with the varying demands made upon the sporogenous cell during spore-formation, a process analogous to the absorption occurring in certain of the higher plants when cells of the suspensor prey upon surrounding tissue for the nutrition of the embryo (11). Such departures are clearly only valuable for classificatory purpose within narrow limits. A conjugation preliminary to spore-formation indicates, however, greater morphological fixity, and must be differently regarded. No one of the species here described can therefore be appropriately compared with Chondria tenuissima in the more characteristic features of the development of the cystocarp.

With regard to the opinion which I have already expressed, that the pericentral cell is to be regarded as the auxiliary cell, rather than its derivative formed subsequently to fertilization which I have called the sporogenous cell, it is clear that the matter cannot be determined until the conjugation of the carpogonium with an auxiliary cell has been observed. Schmitz's success in observing the corresponding process in Ceramiaceae leads one to expect that this may soon be done. Should conjugation be found to take place with the pericentral cell, before the sporogenous cell is shut off, then the 
pericentral cell is the auxiliary cell; if with the sporogenous cell, after it has been cut off, then that cell is the auxiliary cell, as is contended by Schmitz. In default of this evidence there is, however, this difficulty in regarding the derivative cell as the auxiliary cell, that it is not cut off when fertilization does not take place; and if it be separated in consequence of fertilization, but before conjugation with the carpogonium, it is necessary to assume the transference of the effect of fertilization in some indirect manner, which, while it is not inconceivable, is still an unnecessary assumption, in this case. For division of the auxiliary cell into a sporogenous portion and a sterile portion is found by Schmitz to take place in Callithamnion, and the same statement is made for the carpogonium itself in Nemalion multifidum.

\section{Method.}

The method which I have found most convenient for observations on procarps is that which has been recommended by several others, viz. prolonged treatment with strong glycerine after staining, preferably with Hoffmann's blue. No stain is required in many cases. This treatment causes the transparent cell-wall to swell greatly, and the interior of the procarp is observed through the gaps between the opaque cell-contents. While this method does not involve any change in the relative positions of cells, it must be remembered that all the figures accompanying this paper are drawn by means of the camera lucida from preparations in which the cells are much farther apart than they are in nature. The outlines of the cells are the limits of the opaque contents. The pit-connexions characteristic of the Florideae are an invaluable indication of the genetic relationship of the cells. 


\section{Bibliography.}

1. Analecta algologica; J. G. Agardh. Lundae, I892, p. I 29.

2. Species, genera, et ordines algarum; J. G. Agardh. Lundae, $184^{8-} ; 6$.

3. Untersuchungen iiber die Befruchtung der Florideen; Fr. Schmitz, Sitzungsber. der Berliner Akad. der Wissensch. Berlin, 1883. English translation, W. S. Dallas; Annals and Magazine of Natural History, I 884.

4. Systematische Übersicht der bisher bekannten Gattungen der Florideen; Fr. Schmitz, Flora, Heft 5, 1889. Marburg, I 889.

5. Callosities on Nitophyllum versicolor; Johnson, Proc. of R. Dublin Soc. N. S., Vol. vii. p. I55.

6. Kleinere Beiträge zur Kenntniss der Florideen, I ; Schmitz, La Nuova Notarisia. Series III, I 892, p. III ; Series IV, I893, p. 226.

7. Ibid., Series III, I892, p. II 7 .

8. Notes sur le Développement du Cystocarpe dans les Floridées; Ed. de Janczewski, Mém. de la Soc. Nat. de Cherbourg, 1876 .

9. Etudes phycologiques; Bornet et Thuret. Paris, 1878 .

10. Algen im weitesten Sinne; P. Falkenberg in Schenck's Handbuch. Breslau, I89I, p. I92.

11. Traité de Botanique; Ph. Van Tieghem. Paris, I89I, p. I32I, p. 9I2.

12. A revised list of British Marine Algae; E. M. Holmes and E. A. L. Batters. Annals of Botany, Vol. V, p. 93, I89o.

13. The Algae of the Arctic Sea; F. R. Kjellman. Stockholm, I883, p. I Io, P1. 7 .

14. Florideernes Morphologi; J. G. Agardh. Stockholm, I879, p. I50. Morphologia Floridearum; J. G. Agardh. Lundae, I880, p. 273.

15. Über Axillarknospen bei Florideen; Kny, Festschr. Ges. Naturforsch. Freunde zu Berlin. Berlin, 1893 .

16. Bidrag til Polysiphonia's Morphologi ; Rosenvinge, Bot. Tidsskrift, Copenhagen, I 884 .

Postscript. - This paper had already left my hands before the sad news of Professor Schmitz's death at Greifswald reached me. It is difficult to exaggerate the loss which algological science has sustained by the death of so able and untiring an investigator. 


\title{
EXPLANATION OF FIGURES IN PLATE X.
}

\author{
Illustrating Professor Phillips' paper on the Development of the \\ Cystocarp in Rhodomelaceae.
}

Figs. I, 2, 3, 4. Rhodomela subfusca, fresh material.

Figs. 5, 6. Polysiphonia violacea, alcohol and glycerine.

Figs. 7, 8, I0, I I, I2. Polysiphonia nigrescens, alcohol and glycerine.

Fig. 9. Polysiphonia fastigiata, alcohol and glycerine.

Abbreviations : aux. c. auxiliary cell ; c.c. central cell; cp. br. carpogonial branch; carp. carpogonium; cpsp. carpospore; conj. $m$. mass resulting from conjugation; in. st. br. inferior sterile branch; l. st. br. lateral sterile branch; $p c$. $c$. pericentral cell; $p c p$. pericarp; $p n$. paranema; st. br. sterile branches; tr. trichogyne.

Fig. I. $\times 800$. Surface view of unfertilized procarp, showing the bivalve character. Fig. 2. $\times 800$. Median view of unfertilized procarp, showing the carpogonial branch shaded black, and the sterile branches shaded red.

Fig. 3. $\times$ I 200. Median view of contents of procarp, just after fertilization. The sterile branches have developed and the auxiliary cell divided. No spores are yet formed.

Fig. 4. $\times 600$. The cystocarp after spore-formation. The spores are seen to radiate from the sporogenous cell. The sterile branches are intact. The carpogonial branch, from which the carpogonium has disappeared, is shunted near the pore.

Fig. 5. $\times 800$. Median view of unfertilized procarp from behind. The lateral position of the carpogonial branch is seen, with a sterile branch facing it. The trichogyne is bent where it leaves the procarp.

Fig. 6. $\times 800$. Contents of procarp somewhat later than Fig. 3. Spores are seen arising from the sporogenous cell.

Fig. 7. $\times 800$. Median view of procarp just after fertilization, showing origin of the paranemata.

Fig. $8 . \times 400$. Median view of a nearly mature cystocarp, showing development of paranemata.

Fig. 9. $\times 800$. Lateral view of the product of one of the two cells giving rise to the paranemata (dotted). The auxiliary cell, sporogenous cell, and carpogonial branch are shown. The sterile branches and spores are omitted.

Fig. I0. $\times 800$. Surface view of procarp, showing the origin of one of the valves of the pericarp in a single pericentral cell.

Figs. II and I2. Masses squeezed out from nearly mature cystocarps, showing pitconnexions with sporiferous filaments.

Figs, I3 and I4. Diagrammatic representations of the contents of a procarp before and after fertilization respectively. 


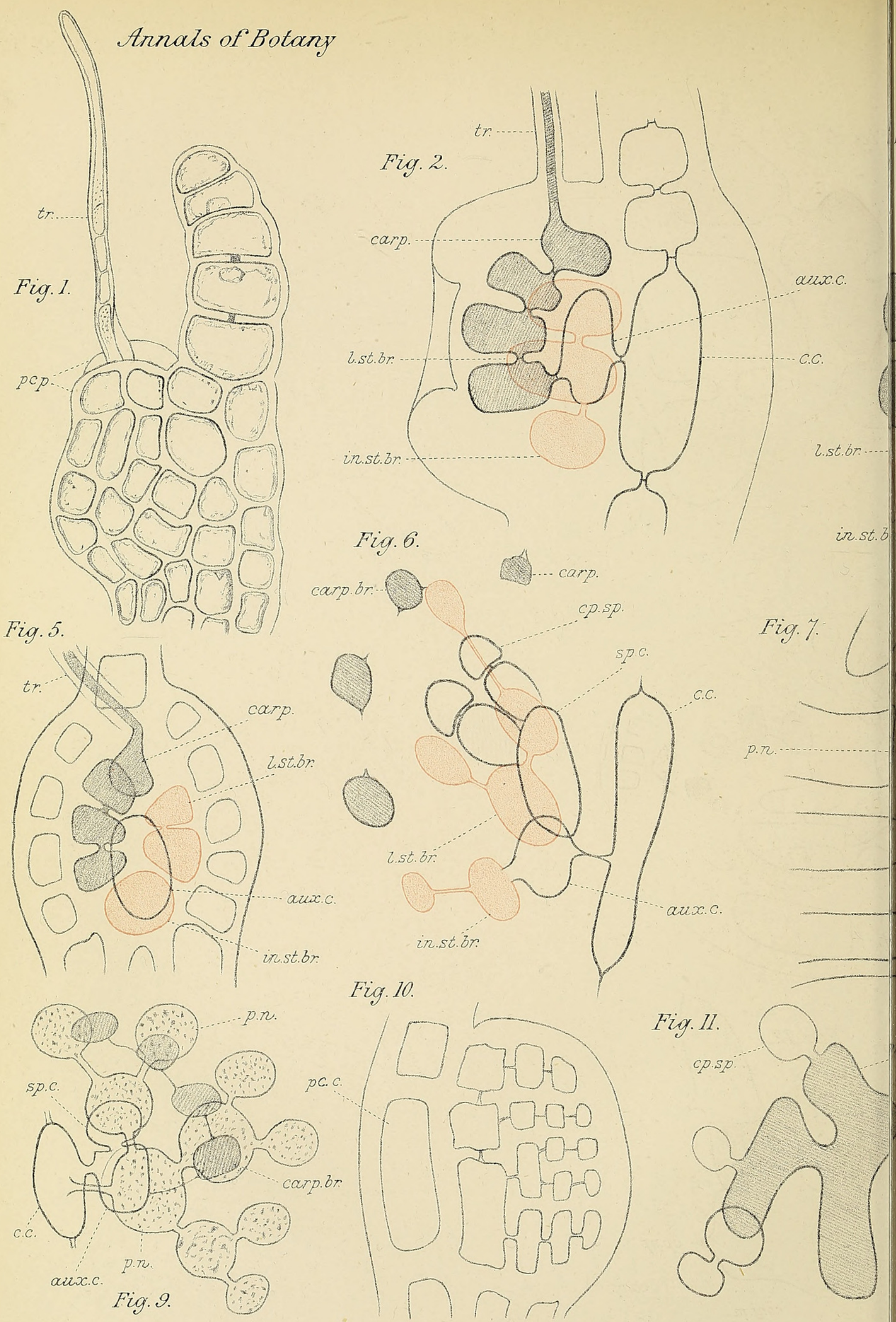

R.W.P. del. 

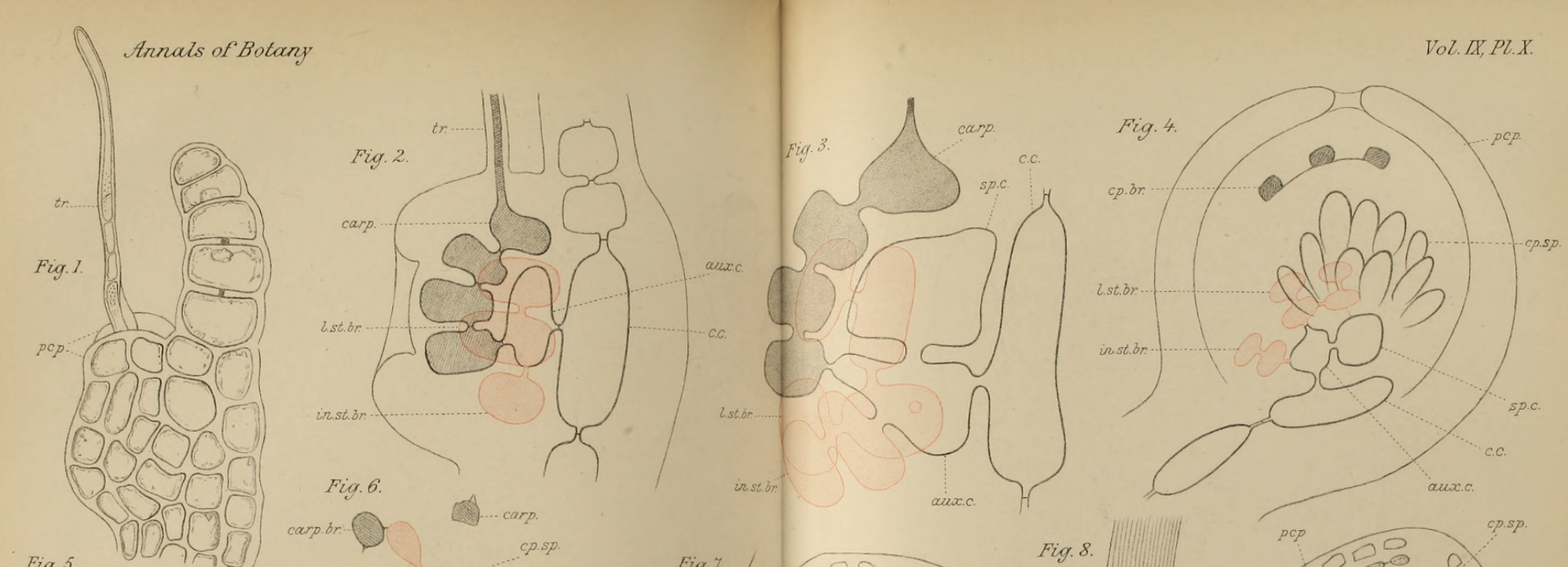

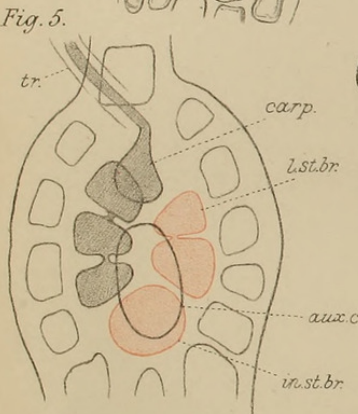

a)

(

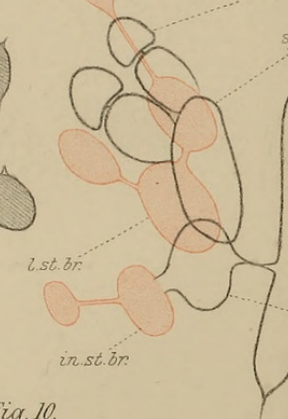

Fig. 10.

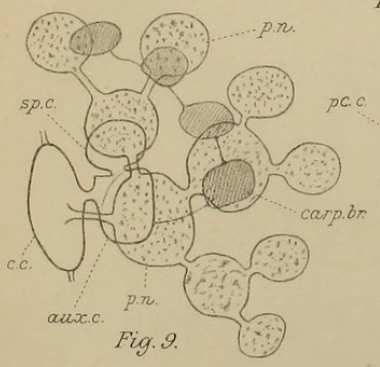
R.W.P. del

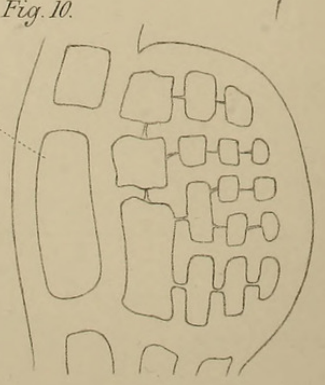

spc. Fig. $\%$

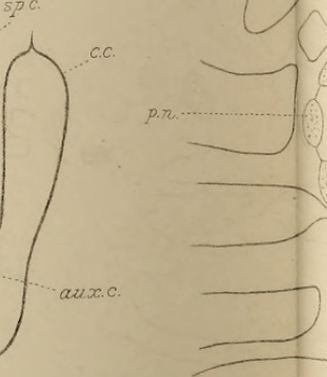

Fig. Il.

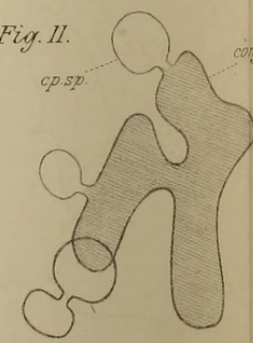

PHILLIPS. - RHODOMELACEAE.
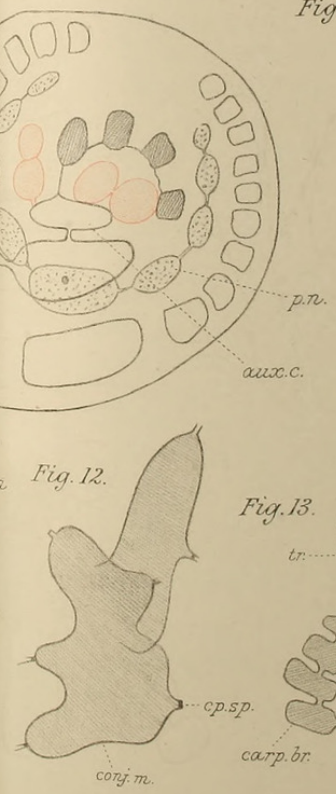

Fig. 13

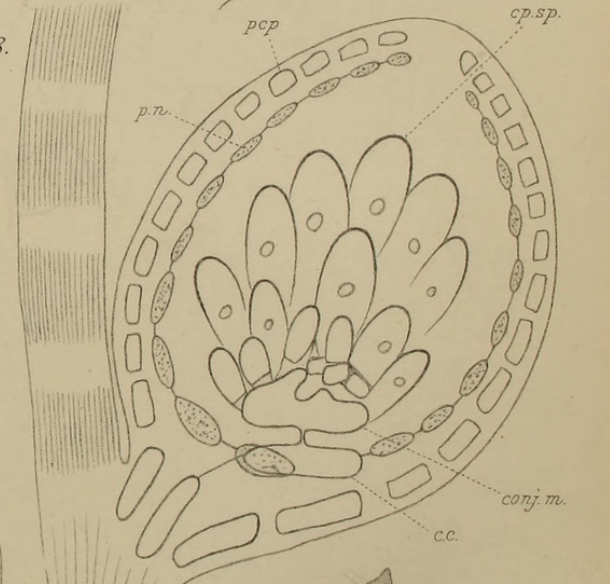

Fig. 14. 9

aux.c. st.bn 


\section{$2 \mathrm{BHL}$ Biodiversity Heritage Library}

Phillips, Reginald W. 1895. "On the development of the cystocarp in Rhodomelaceae." Annals of botany 9, 289-305.

https://doi.org/10.1093/oxfordjournals.aob.a090739.

View This Item Online: https://www.biodiversitylibrary.org/item/233478

DOI: https://doi.org/10.1093/oxfordjournals.aob.a090739

Permalink: https://www.biodiversitylibrary.org/partpdf/318379

\section{Holding Institution}

Smithsonian Libraries

\section{Sponsored by}

Biodiversity Heritage Library

\section{Copyright \& Reuse}

Copyright Status: Not in copyright. The BHL knows of no copyright restrictions on this item.

This document was created from content at the Biodiversity Heritage Library, the world's largest open access digital library for biodiversity literature and archives. Visit BHL at https://www.biodiversitylibrary.org. 